\title{
The Structural Changing Phases of Ifè Festivals and Tradition Towards Economic Boost and Cultural Tourism
}

\author{
Adéolá Adijat Fáléye \\ Obafemi Awolowo University, Nigeria. \\ yeyeadeola2016@gmail.com
}

\begin{abstract}
Festivals provide information on the origin of beliefs, historical antecedents, socio-cultural and socio-political desires, meant for bonding. The resultant effect of participation in festivals enables the participants to protect and sustain the festivals. However, our research informs that a number of the official festival activities with the tones of its referred sacredness in Ilé-Ifẹ̀, which is the domain of data collection and subject of our analysis, are being restructured in outlook and content to boost the economic survival of the people; and for cultural tourism. This essay seeks to interrogate these structural reforms, with the mind of identifying improved areas of the age-long tradition, the philosophy of the festival, and the economic value added. The apparatus of analysis shall premise on cultural semiotics and sociology of literature.
\end{abstract}

\section{Introduction}

Festivals are simply celebrations of important reference, molded up in various activities that bring diverse people together at particular seasons; for the realization of a specific goal. The goal is often connected to the remembrance of one primordial, human-deified, or living ancestral accomplishment. Such celebrative accomplishment in reference could be that of individual or collective efforts, as it is evident of most Yorùbá festivals. This act of remembrance in celebrative mood or that which calls for sober reflection, as the case may be, is also universal as documented in other nations' festivals. In this study, we shall be discussing three age-long tradition and elaborately celebrated festivals of Ilé-Ifẹ̀. The festivals are Oloọjoọ, Mọrèmi (also known as Edi) and Ajé. 
The submission to the Supreme Being (God), as the creator of all beings and the relevance of his supremacy amidst celebration of other divinities of importance among the Yorùbá people is what Adéoyè (1979) accounts for, thus:

Èyà Yorùbá jẹ èyà tí ó gbà pé Olódùmarè ni Ọba tí ó ju gbogbo ọba lọ, ọba tí ó rínú rode, tí ó si dá ohun tí n' be lábẹ́run ayé àti ọrun... İgbàgbọ àwọn baba n'lá wa ni pé àwọn Irúnmale àti àwọn òrișà tàbí À kàndá ẹdá wa láàrin Olọ́run àti àwa ẹ dá ọwo rẹe, tí ó dá sí ilé ayé; àwọn Irúnmalẹ náà ni: Ọbàtálá, Ọrúnmilà, Ògún, Eșù àti Ṣàngó... (9-11)

The Yorùbá, are a nation that belief in the supremacy of God-Olódùmarè, as above all other kings; a king that sees all, and who created all things that under the sun of the universe [...] the belief of their forefathers also supports that the divinities also exist among them and the special species of the creations of God that lives on the earth....among these divinities are the Ọbàtálá, Ộúnmilà, Ògún, Ėṣù and Șàngó... (My translations)

The above cited submission is a shared notion to establish the fact that, while the Yorùbá have the significance of their creator at the center-point, in celebrating the intermediaries called the òriṣa - the divinities - for their incomparable accomplishment, the people are ever mindful of the supremacy of the most-High God. It is also evident that the divinities they honor either come in such a joyous or sober reflection as what the tones of Ifẹ̀ festivities signify in some cases.

\section{Focus and Aims of Study}

Needless to state that in spite of the modern festivities around in the globe, festival performance in Africa remains one socio-cultural capital that appeals to people from different layers of the society, with the capability to facilitate healthy, social, and communal bonds, as well as promoting the traditional heritage of the people. Several interesting icons of note are identifiable around Ifẹ festivals. Therefore, the aim of this study among other things shall be to reflect on the altering and reconfiguration of modes of celebration of festivals in Ifẹ̀. We observed some changes which are connected to the content of the activities, the outlook of the locations of the celebrations, and participants as against what operated in the past years. This study therefore hopes to be able to justify the relevance of the celebration continuation, considering the relevance of the changes. 


\section{Current Survey on Ifẹ̀ Festivals}

Ilé-Ifẹ is known as the cradle or the source of the Yorùbá people. Ògúnfọlákàn (1996), Olúpọ̀nà (2011), and Adélékàn (2014) are of important reference to this study. In addition to these scholars' views, there is a record of common saying by the people of Ilé-Ifẹ that, everyday is celebration in IléIfẹ̀, except one, and only the king (Ọ̣ni) knows this exceptional day - gbogbo ojọ́ lọdun n’Ífẹ, àyàfi ọjọ́ kàn. Oọni nikan lo si mọ ojọ́ ti wọn kì í fí sọdun ọhun. The truth of this excerpt is evident in the historical documentations of scholars such as Adélékàn (2014) and Olúpọ̀nà (2011) that, everyday life of the people is woven around one celebration or a particular festival in Ilé-Ifẹ̀. In the field research carried out between 2016 and 2019 for this essay, there is no gainsaying in re-echoing the fact contained in the Yorùbá except above; as everyday truly accommodates one type of celebration connected to the priest of a divinity, taking place at the king's palace, or/and in the public domain.

Our current three years' survey is a confirmation of the view that Ilé-Ifẹ has more than 401 legends and heroines that the community identifies with; as they bring them out during the various festival celebrations. Depending on the heroes or heroines, goddess or gods involved, some of these festivals are celebrated with fun-fair. As it was in the very past of Ilé-Ifẹ̀, it is such that priests and family custodians of most divinities take care of the sacred aspects of the propitiation required, while just few people who are initiates participate in the annual celebration.

As one of our informants conveyed to us during our field research, it is imperative to also know that the names of the festivals in existence as of the ancient days in Ilé-Ifẹ̀ have pragmatically not changed. ${ }^{1}$ The names and compound priests or custodians of the divinities are also kept and maintained till date. The vacant stools of some custodians to some festivals were filled with new chief priests to make sure that no festival is missed out in the circle of propitiation and celebration. Examples of the festivals as we surveyed in tandem with earlier scholars' documentations are: Pòkúlere, Edì/Mọrèmi, Odùduwà, Olókun, Ajé, Olúorogbo, Ộànmíyàn, Òràmfè , Ọyárọ̀, Aláfẹrẹ, Ọbamerì, Ọbaresé, Ọdún-Ọmọ-Ọwá-Ọ̣ni, Ọlọ́jọ́, and many others still celebrated in Ilé-Ifẹ̀.

In reference to some changes in discussion, and in agreement with Ògúndèjì's (2002) submission, the performances within a traditional festival are such that:

1 Olóyè Ẹmẹsẹ Olórí Èkeje- popularly called İbilẹ is one of our informants as the traditional Ẹmẹsẹ in charge of most links to festival propitiations at the palace and the liaising officer to other Chief Priests of the Ifẹ̀ divinities. 
[T] he ritual festival is more prominent and larger in scope than the sacred ritual... sacred ritual performance emphasizes the religious and worship more than the entertainment or the aesthetics, while ritual festival performance gives equal emphasis to the religious and the aesthetic...The aesthetic aspect is still very present but not so much as in festival ritual performances (14).

In context of the festivals under study here, our observation is that the Olọ̣jọ́, Mọrèmi / Edì and Ajé festivals would have retain their categorization as the sacred ritual festival; however, looking at the new outlook, we see the ceremonies surrounding the three festivals as graduating to accommodating the features of cultural ritual festivals. This is not to say that the sacred ritual aspect of the festivals is lost. With the face-lift both in content and outlook, we have no doubt that the sacred aspect of the festivals is still intact. However, the Olọ̣jộ, Mọrèmi/ Edì and Ajé festivals have expanded the scope of their openness to more participants with the inclusion of carnival which underscores the sacred features for a more welcoming ritual cultural celebration in recent times.

\section{About the Selected Festivals}

As we mentioned earlier, this study shall specifically review the celebrations of three Ilé-Ifẹ̀ festivals observed between the years 2016 and 2019, spanning the first three years of the incumbent monarch on the throne. The festivals are Olọ̣jọ́, Mọrèmi / Edì and Ajé. These festivals are now known to be elaborately celebrated. While Olọ̣jọ́ festival is the major official festival connected to the propitiation of Ògún - as a divinity of the primordial time, and the wearing of the sacred arè crown by the king, Mọrèmi / Edì and Ajé festivals are linked to feminine divinities. The Mọrèmi or Edì festival is connected to the celebration of a woman legendary called Mọrèmi. Her narratives exist both in oral and written accounts of some authors like Débò Awẹ́ (2017), Ògúnrẹ̀mí (2018), and others. All Ifẹ̀ traditional chiefs and the İsòrò play important role during the festival, but the Osògún and Oọ̀ni play crucial role during the celebration. The festival holds yearly within the later parts of September and early October.

Mọrèmi or Edì festival is celebrated in remembrance and honor of the wife of Ọrànmíyàn. A woman whose legacy transformed her into a deified divinity, as a result of her immense contributions to the liberation of the Ifẹ people from the oppression of Ugbo invaders of the ancient history. The festival is often for the singular remembrance of issues related to Mọrèmi's unparalleled personality to have sacrificed her only son - Olúorogbo - for the liberation 
of all. So, the celebration of the festival presents Oọnni as a role model, teaching the youths, especially women, the lesson of selfless service, unconditional love, bravery, and boldness among other virtues. The festival holds yearly in the month of July/August.

Ajé is a feminine goddess whose festivals is meant to honor the divinity of wealth and business. The location of the shrine is not far from the current Òkèmògún shrine; close to the ancient market called Ojà Ėjìgbòmẹkùn which was the first market where Ajés stalls were said to be spotted at the primordial time. The festival pulls largest crowd than other festivals in Ifẹ̀. All main İsòrò traditional priests of Ifẹ have roles to play at the shrine and within the palace during the festival. The festival holds within the month of February yearly.

\section{Evaluating the Structural Changes}

Our findings show that most of the people want their tradition protected. No doubt, when such age-long, ancient matter is carelessly handled by any stakeholder, the king or the custodians of the festival, and the community at large mostly frown at such moves. In order words, the king and the community retains the potency and vibrancy of any celebration connected to the festivals, through their action and responses to such events. Our further findings on Ifẹ̀ selected festivals show that while some communities go against improvement of any kind because of their conservative views, others are impressed that there is an inclusion of modernity to entice people into their community. Often, most Ifẹ people who have contact with other people's culture are found embracing this move within their locality. However, some who may or may not belong in the elitist class, but who have very strong commitment to their community development, tradition, and the preservation of their values, do not bother so much about any alteration; so long the sacred aspects of the traditional heritage are not tampered with. In some contexts, the youths and adults alike often embrace and welcome such modern inclusion in their make-up activities for the community. However, reflections on Ifẹ peoples' reaction to the series of changes evident in the order of festival activities and the architectural modifications were initially with mixed-feelings.

We also found that most of the new innovations added to the age-long festivity are in the songs and the nature of dresses called aṣo ẹbi or ẹgbéjọdá (family uniform), which signifies oneness. The other area of changes that is prominently evident is in the face-lifts or re-building of some shrines or groves of the divinity. This is evident at Òkèmògún shrine where the main propitiation of Ògún was given a befitting face-lift, painted in white, with a proper gate to protect the entrance to the grove. 


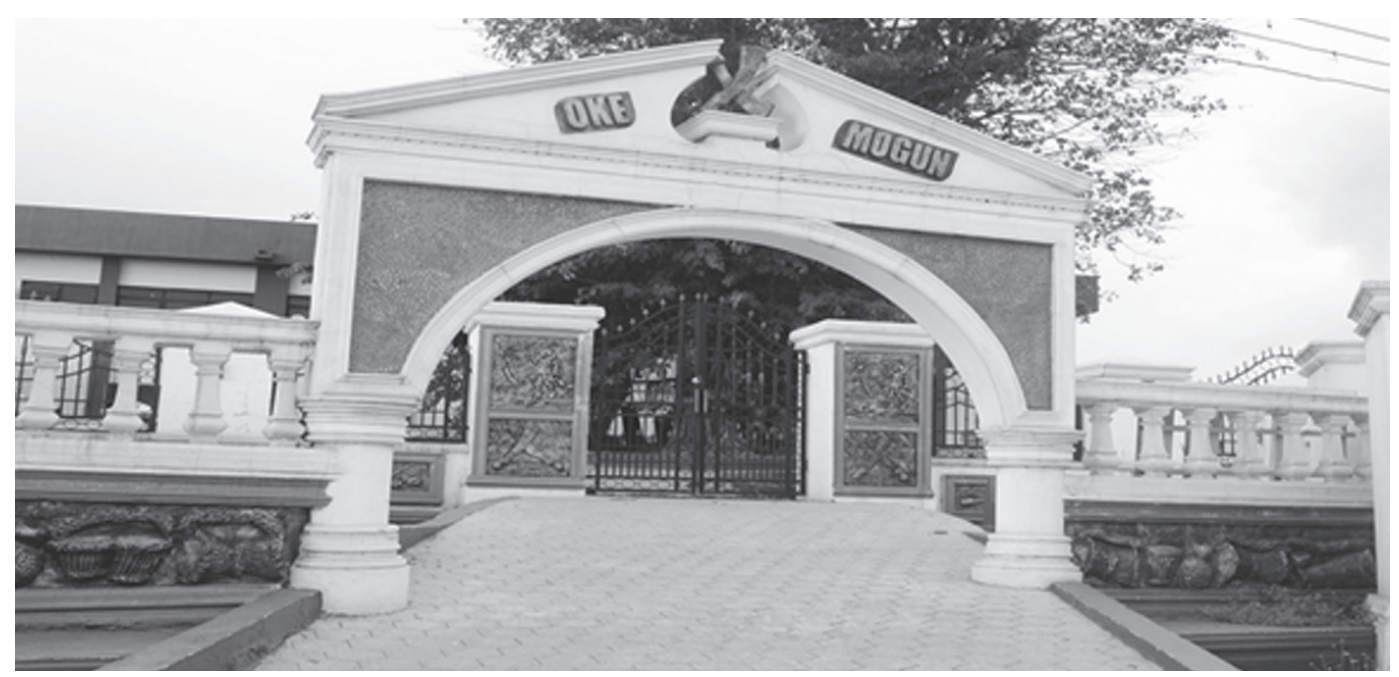

Fig 1: The entrance to Òkèmògún shrine renovated in 2016

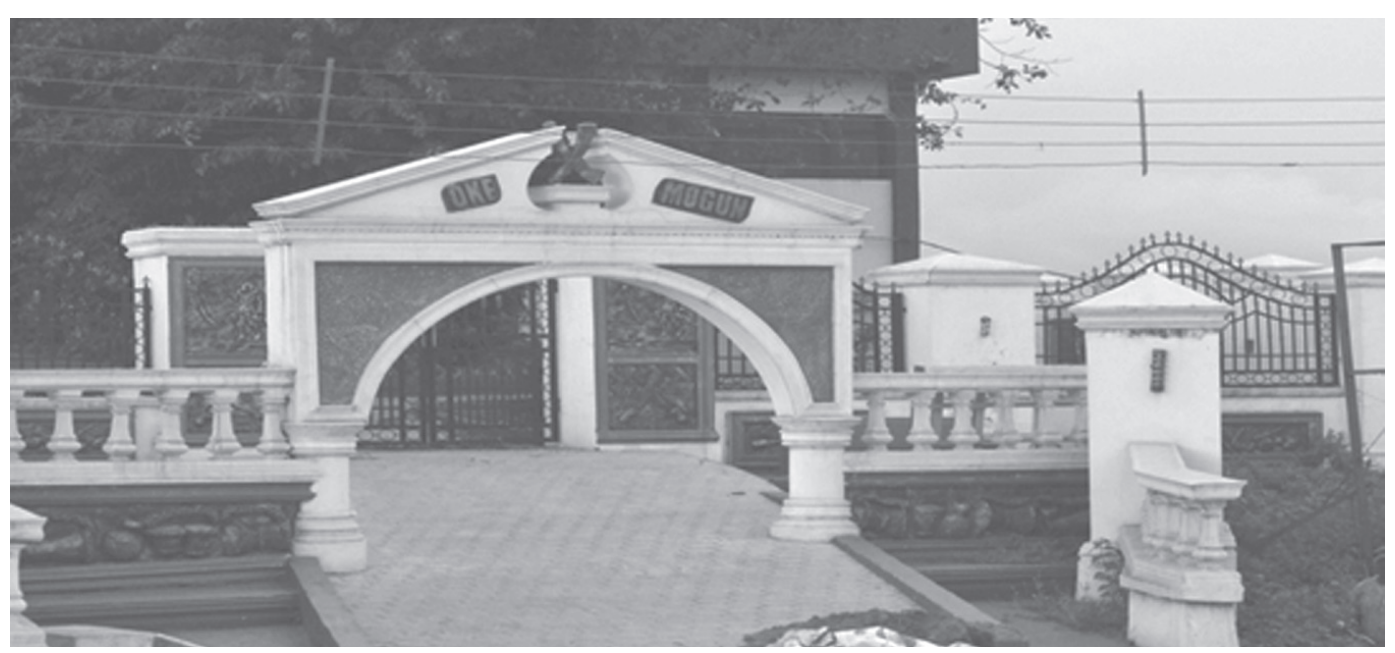

Fig 2: Far-view to the back section of Òkèmògún shrine

This renovation prevents people from gaining free access to the shrine. The shrine became modern in outlook while retaining the historical spots for the sacred aspect of the festival with the existing pèrègún and other ancient trees intact. There are ornamentations round the walls and entrance gate which conspicuously inform non-natives or non-Ifẹ̀ indigenes that there is truly a shrine at the center spot of Enuwá; a location not too far from the palace. 


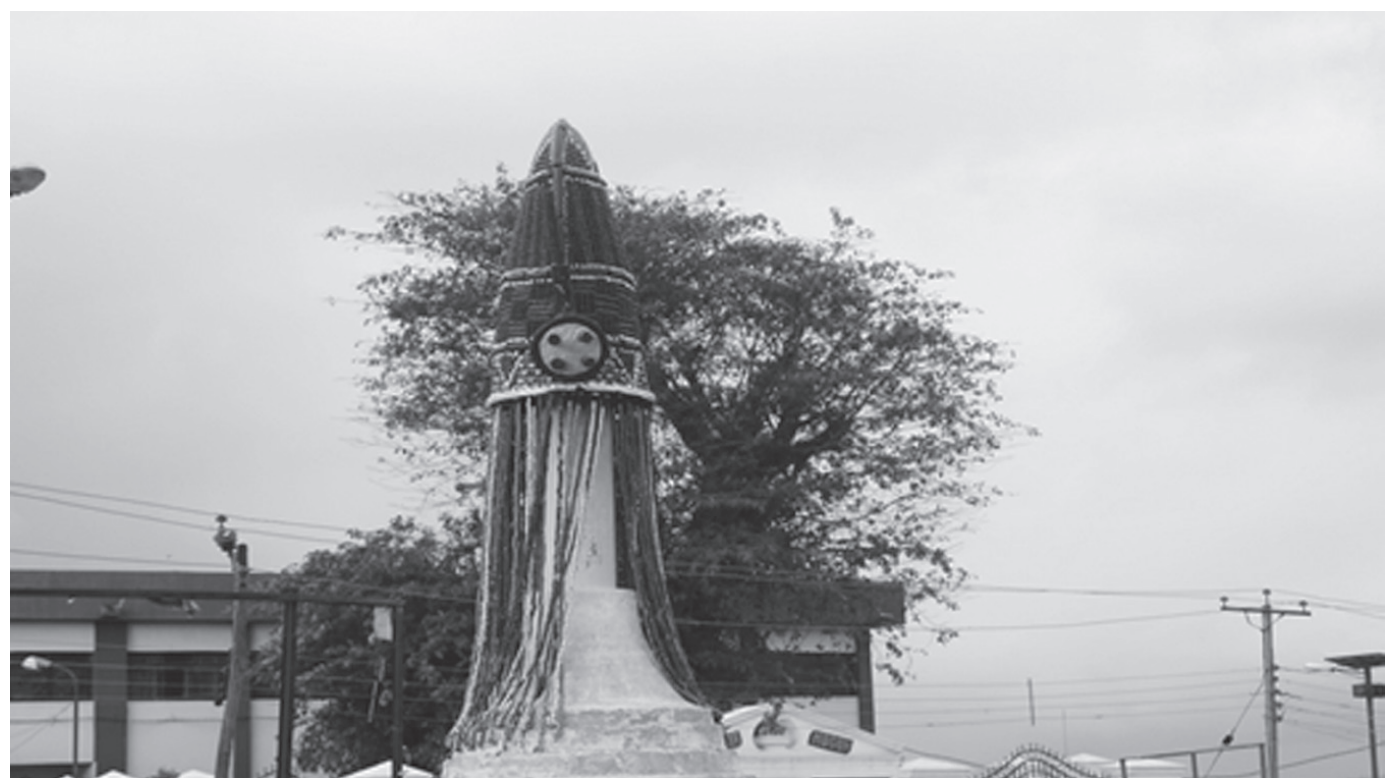

Fig 3: The protected Òkèmògún shrine

Also, is the Mọrèmi shrine along İtakọgun in Ilé-Ifẹ̀. The location is behind the palace, it became a new edifice, with a modern effigy of the woman (Morèmi) for people to behold and tour, even though as the sacred locations of the priest-custodian of the festival - Yékéré and Èrí remained protected within.

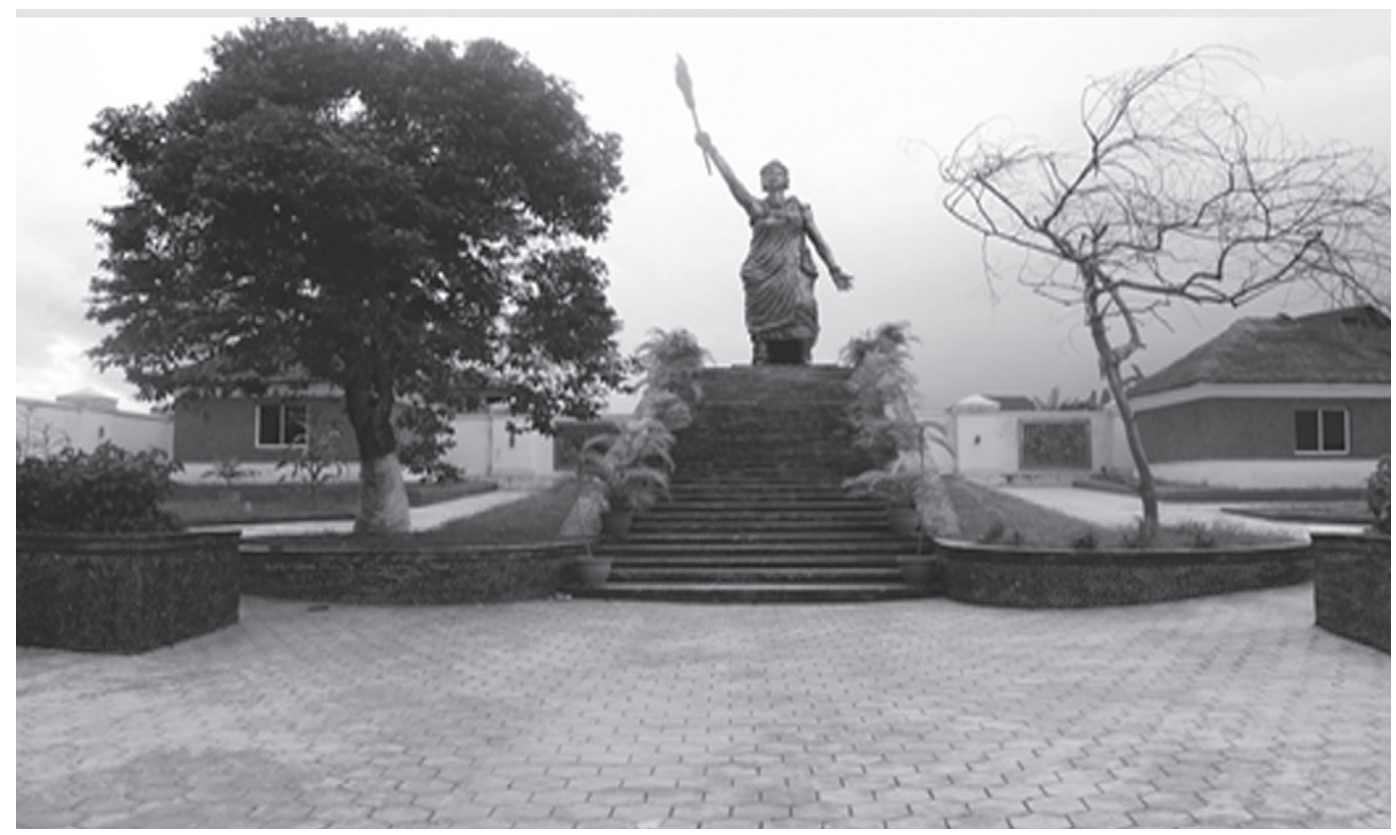

Fig 4: The interior part of Morèmi shrine (house) and the effigy along İtakogun in Ilé-Ifè 


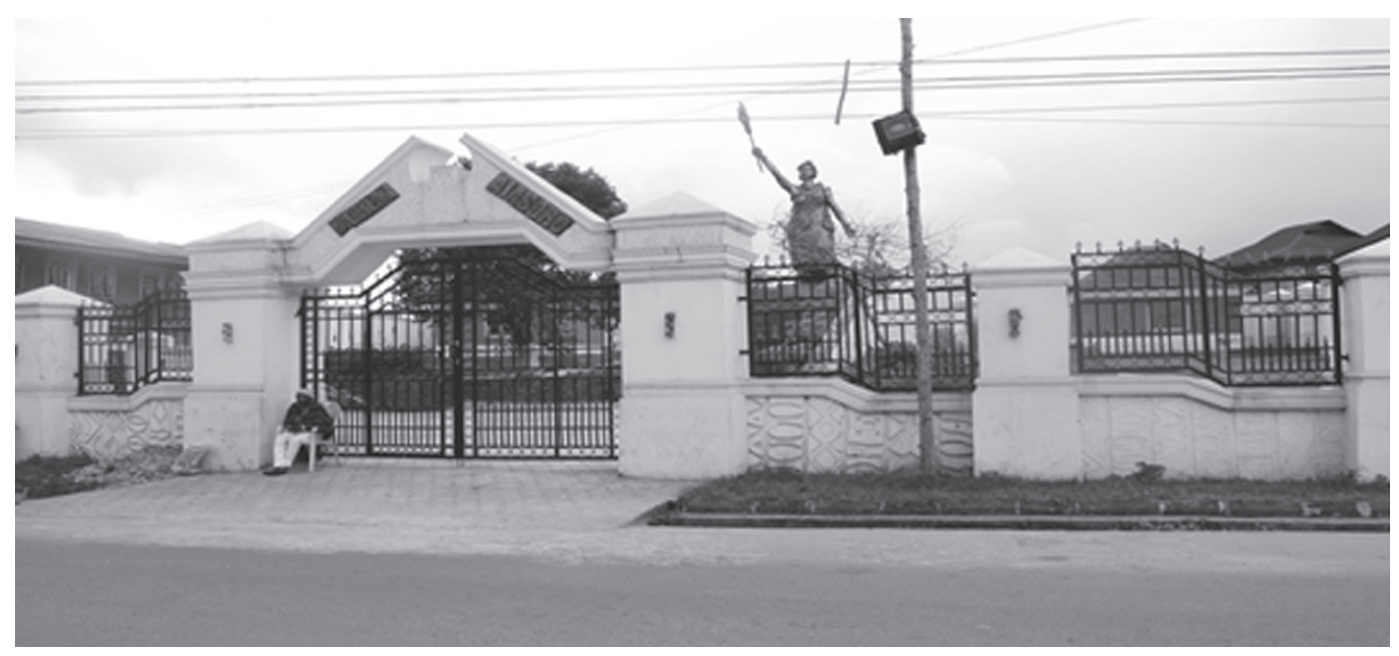

Fig 5: Entrance to Mọrèmi shrine (house) along İtakọgun in Ilé-Ifẹ

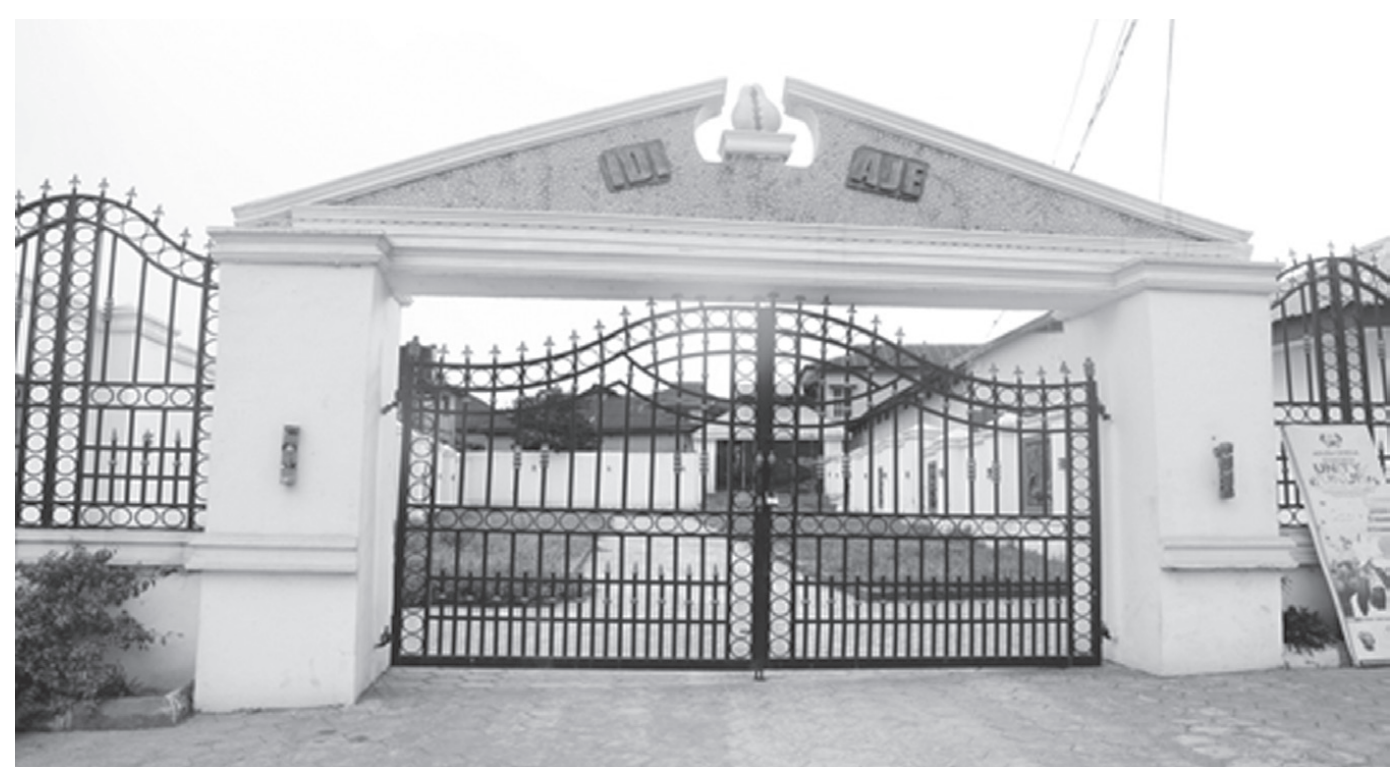

Fig 6: Entrance to Ajé shrine in Ilé-Ifẹ

There is also a gate to secure the new building from miscreants, but it is open to the public to view, on consultation. The shrine was outstandingly carved out, in white, with a modern outlook, leaving the propitiation spot sacred inside, as it were, but with some fascinating adornment. These changes will be analyzed in the remaining section of this essay.

\section{Relevance of the Structural Changes}

Our interrogation is premised on the significance of the continuation of three Ife festivals - Olọ́jọ́, Mọrèmi / Edì, and Ajé - in an elaborate manner. Also, we would like to discuss the relevance of the changes made to the 
age-long traditions that have turned into tourist sites for visitors coming from all over the globe. As we have enumerated above, there is no doubt that some basic structural changes have taken place in the way the three selected festivals are celebrated while some relevant aspects are still intact till date. We shall discuss some of the signifiers of the structural changes now.

\section{Preservation of the Priests and Family Custodians}

The priests and family custodians are still in charge of the core sacred aspects of the festival. People now have access to both the sacred aspect of the festival and the carnival which is opened to all and sundry. The need to retain this tradition is essential to train the younger ones for knowledge which the new generation may not have acquired.

\section{Cultural Friendly for Tourism}

Our research shows that apart from the people yearning to know more about the history, and other narratives of the Ilé-Ifẹ people, the need to make festivals accessible and inviting in modern age, and in each community to be a cultural tourist-friendly is essential. This is becoming a reality in the case of the three Ifẹ festivals under discussion. We consider that most of what the incumbent monarch aims to achieve from the various steps he took since his ascension to the stool of his forebears seem to have motives towards changing the low quality of the celebrations of the official festival of the community to an inclusive ceremony for all. This is evident in the large turn-out of people for the three years we recorded compared to the past celebrations. Also, the signifying motive is to make the celebrations annual festivals, which can in turn boost the economy of the Ilé-Ifẹ and its environ. This has been achieved directly and indirectly as revealed by the number of foreigners, important dignitaries across the world, and journalists, who documented the events, and later turned the videos out on social media outlets for commercial values. Such recordings are also relayed on television and radio stations as entertainment clips for people to enjoy from their homes without stress.

\section{Open Accessibility}

The culture of open access to the core sacred aspect of the celebration gives unrestricted access to people who can obey simple rules and regulations. One of the rules is connected to stepping into the shrines without any complications of self and tradition. Another rule states that participants must wear the same color of dress, mostly white, or the preferred color of the divinity. Another rule states that participants must not wear shoes to the grove. Most of these rules are related to neatness and sanctification of the body. For instance, 
a woman who is in her monthly circle is expected to abstain from visiting the divinity grove, although she may view the ceremony from afar. The resultant effect of prior advertisement ahead of the celebration on radio, television, and other social media outlets is to keep the larger public abreast of what to be done in the community. This symbolizes the open accessibility and strength of the positive turn-out of people from different parts of the globe. The sanctity of keeping the taboos, order, and announcement, and the wearing of white attires or uniform is to maintain the traditional laws connected to the festivals in a subtle manner and as preservative method which has positive and functional role in the future of the festival.

\section{Upholding Orderliness}

It is important to state that, we observed the fear of tradition around people even though there is no need for it. Fear as an element put up by several non-indigenes at such a big age-long tradition and cultural event is still evident as the guards called Ẹmẹsẹ or the Lókolóko shielding the monarch from the mob, while maintaining orderliness as well are jealously guarding their traditional office, with their canes. The import of the cases to anyone is warning, even before it is used on anyone who trespasses. These Emẹẹ̀ and the Lókolóko in large number file out as they clear paths for important guests. Today, the efforts of these traditional guards are complemented by the uniformed officers of law at all levels of the festivity. The orderliness maintained by the Emẹsẹ here, is a signifier of proper organization that traditional festivals have always had, even before the advent of modern law enforcement agents.

\section{Cultural Tourism for Economic Boost and Survival}

Culture, we should point out, is as old as human history. As Danesi (2004) considers the importance of culture in human life as, "simply put, without culture, human beings would have great difficulty surviving..." (35). We share Danesi's view that culture remains part and parcel of what makes life a meaningful terrain, with its various diversity and aesthetics. In the context of the three Ifẹ festivals discussed, the cultural acrobatic displays, the gun salutations from the hunters at the Olọ́jọ́ events, as well as eulogies to the monarch during the visit to Òkèmògún, are quite entertaining and nerve racking. Also, the songs and chants, which showcase satire at the Edì festival, for instance, create some fun to the audience. While some songs are sacred, warning the audience of their limitations to closeness to the grove, other songs sound very vulgar and hilarious. Also, the aesthetics as viewed from the celebration of festivals, is linked with the arrays of colorful display of costumes within the 
face-lifted locations. This makes the entire festivals very attractive, encouraging, and worth viewing yearly.

In understanding the human condition, the anthropologist Geertz (1973) writes that, “...without culture, human beings would be unworkable monstrosities, with few useful instincts, few recognizable sentiments, and no intellect" (23). In order words, the totality of a given culture structures the behavior of the people and provides meaningful understanding of their past or life style. This view is mostly evident as the belief system of the people of Ifẹ̀ at the Olộjọ́ is intellectually detonated through their actions. In particular is the respect for the arè crowing day. The attitude of people changes when the king wears the crown and moves around them, blessing them. To most people, at that point in time, the king is seen as the reincarnated Odùduwà, the progenitor of the Yorùbá, with a sacred tongue to bless them. For upholding the beliefs surrounding the name of the festival thus: the day the creator made as the owners' day - ojọ́ tí olọjọ́ dá ojộ, this attitude and the symbolism attached to the aura become intellectual property.

On the second note is the strength attached to the crown with its dual power. On the one hand, the front view is believed to be able to pull rain, while the back-view forces rain to gather but never to fall during the movement of the king while wearing the crown or while he moves to and from the Òkèmògún to propitiate Ògún. Because the propitiation of Ògún must be done at the shrine, as the king also have role to play at the spot, several people are always ready to witness the occasion expecting to receive blessings from the Odùdùwà reincarnate. Some reasons are attached to the wearing of the crown as a symbol of the relevance of the king on the throne, and that any utterance of the king while wearing the crown will come to pass. This is the strength that most sacred or ritual cultural and official festival carries. This cultural belief is what attracts tourists yearly to the festival. Because the sacred arè crown is worn by any incumbent monarch once in a year, with the notion that prayers offered by the king has the potency of coming to pass immediately as offered, several people are encouraged to participate when the Olọ́jọ́ festival announcement is made. 


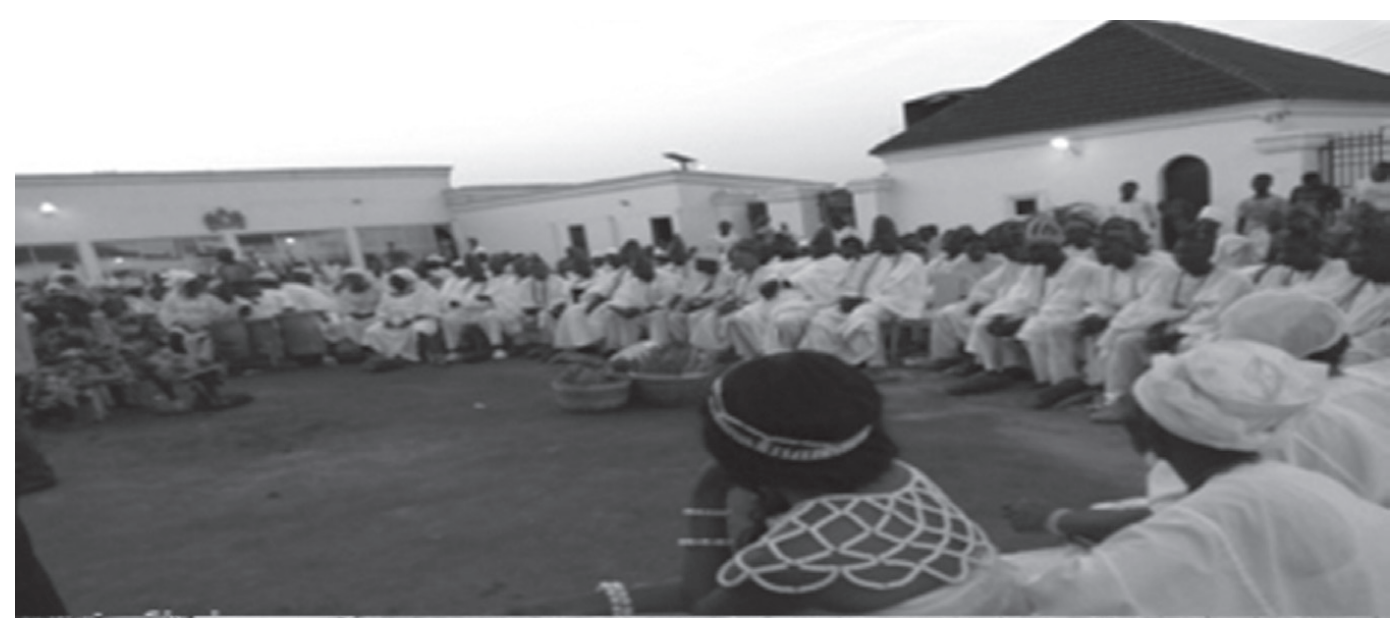

Fig 7: A cross section of participants at the open sessions with the Oọni at the palace during Ajé festival

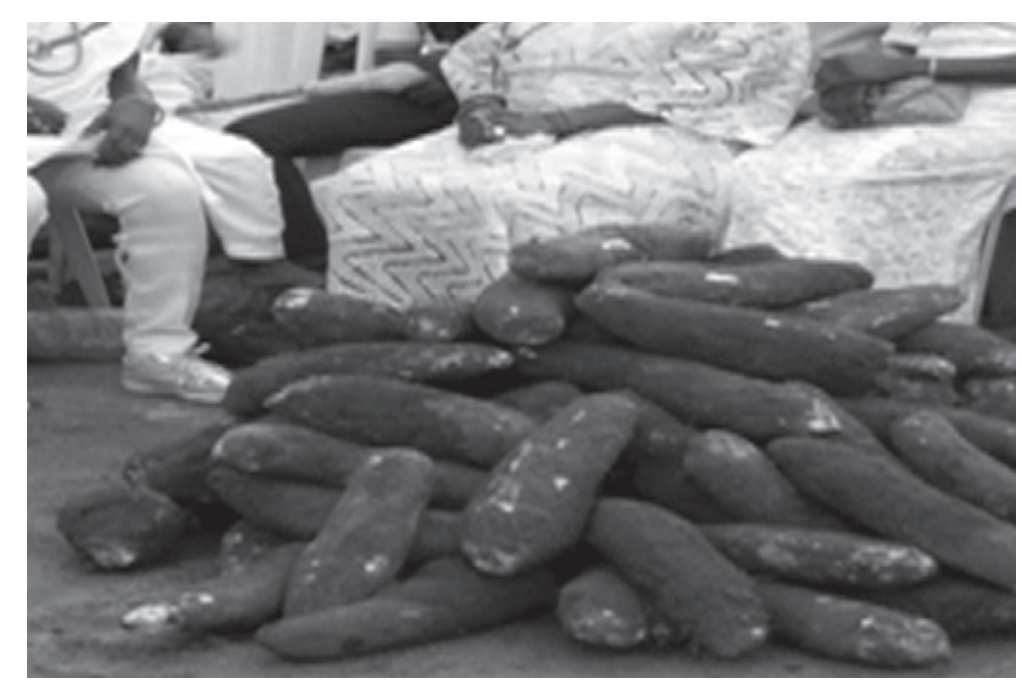

Fig 8: One of the farm crops (yam) such to be shared at the palace during Ajé festival

\section{Increased Foreign/Diaspora Participants}

One notes that more people from the diaspora now visit Ilé-Ifẹ̀ during these festivals. It is not an overstatement that investors and artists of different kinds within and from outside of Ilé-Ifẹ̀ environs now get attracted and fully participate in the festivity. This no doubt informs the economy of the community, the state and the country at large to improve during the festivals. Our reason for this conclusion is evident in the information we received from some of those in the hospitality business. The hoteliers, the small-scale water seller, restaurant operators, bars owners, transporters and others have positive testimonies to share. The interview we conducted show that most hotels 
are fully booked during the pre-opening days and towards the closing days of the festivals.

\section{Inclusion of Educational and Cultural Pageantry Competition}

In commemoration of Morèmi/ Edì festival, there is an inclusion of some educational and cultural pageantry displays. The picture below is evident of what we refer.

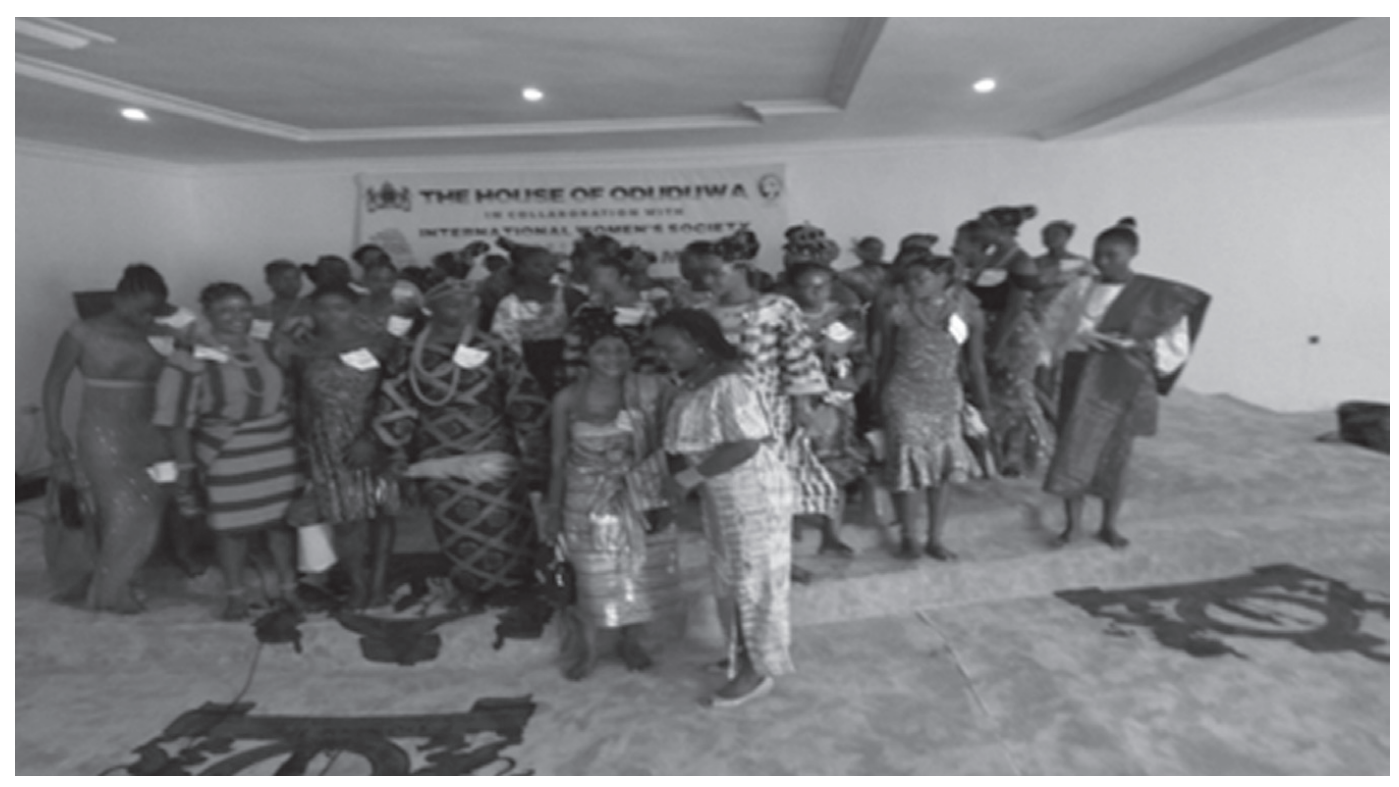

Fig 9: A session of the beauty pageant contestants, as value added to Morèmi/ Edi Festival in Ifẹ

Official and other forms of festive celebrations also continue to serve as the rope that unites and binds people in most societies. The seasonal nature of the event makes the various programs at the season very unique and interesting to people. In fact, nowadays that cultural events wear new look with reference to the added modern activities such as beauty pageant, academic quiz competition, and special academic lectures, as part and main features of the activities within festivals, the scenario in most cases change for the best. People are drawn more to such cultural festivity of the community than what it used to be.

\section{Bridging gap between Man and the Divinity}

In essence, while this official festival equally bridges the gap between man and gods to serve their creator and renew their oaths of allegiance of any kind, the period serves as an economic boost to traders who explore the opportunity of larger crowd and participation to make their livings. With respect to 
the new idea of parade of colorful representations of all divinities, different cultural groups, custodian families related to each of the festivals of Ifẹ as we witnessed during the celebration of Olọ́jọ́ festival, the colorful array of display at the festival, further bring out the sense of visual craft and creativity of the people.

\section{Sense of Visual Crafts and Creativity}

The colorful and symbolic display of all the divinities during the festivals remain a selling point as it presents the heritage of the Ifẹ̀ to the international guests. While some of Ifẹ̀ festivals or divinities are almost not celebrated any longer in the open form for some years past, the symbolic relevance of the current parade as we documented during Olọ́jọ́ festival of 2017 and 2018 is that, the various symbolic representations of such divinities were brought to the fore. The parade and short performances serves as a reminder to the international guests and others in the community to regenerate their thoughts and interest about the existence of such divinities. This, we suppose, is one of the ways the incumbent monarch has enliven the interest of the public towards reviving the celebration of the less researched divinities and for bounding through festivities of Ilé-Ifẹ̀.

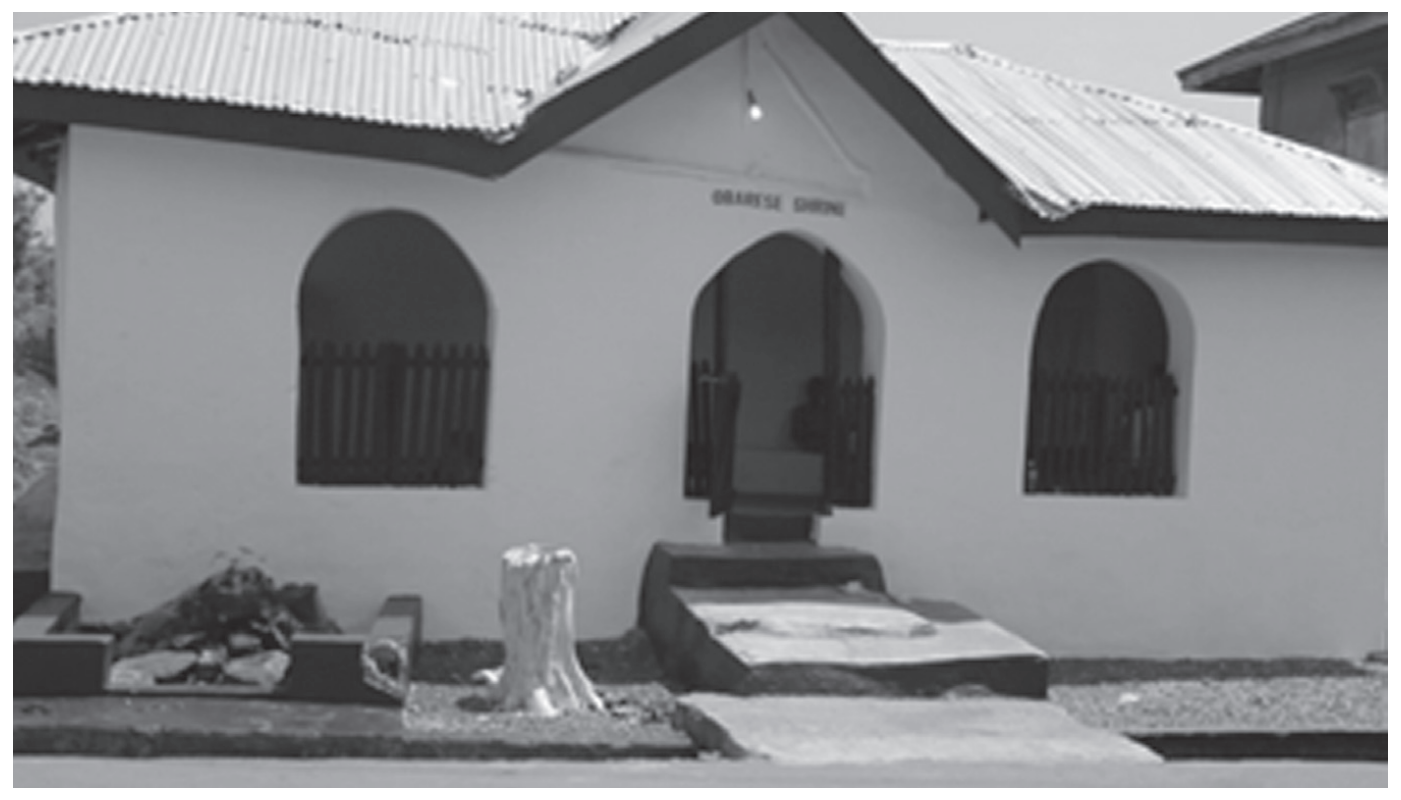

Fig 10: Obaresé Shrine 


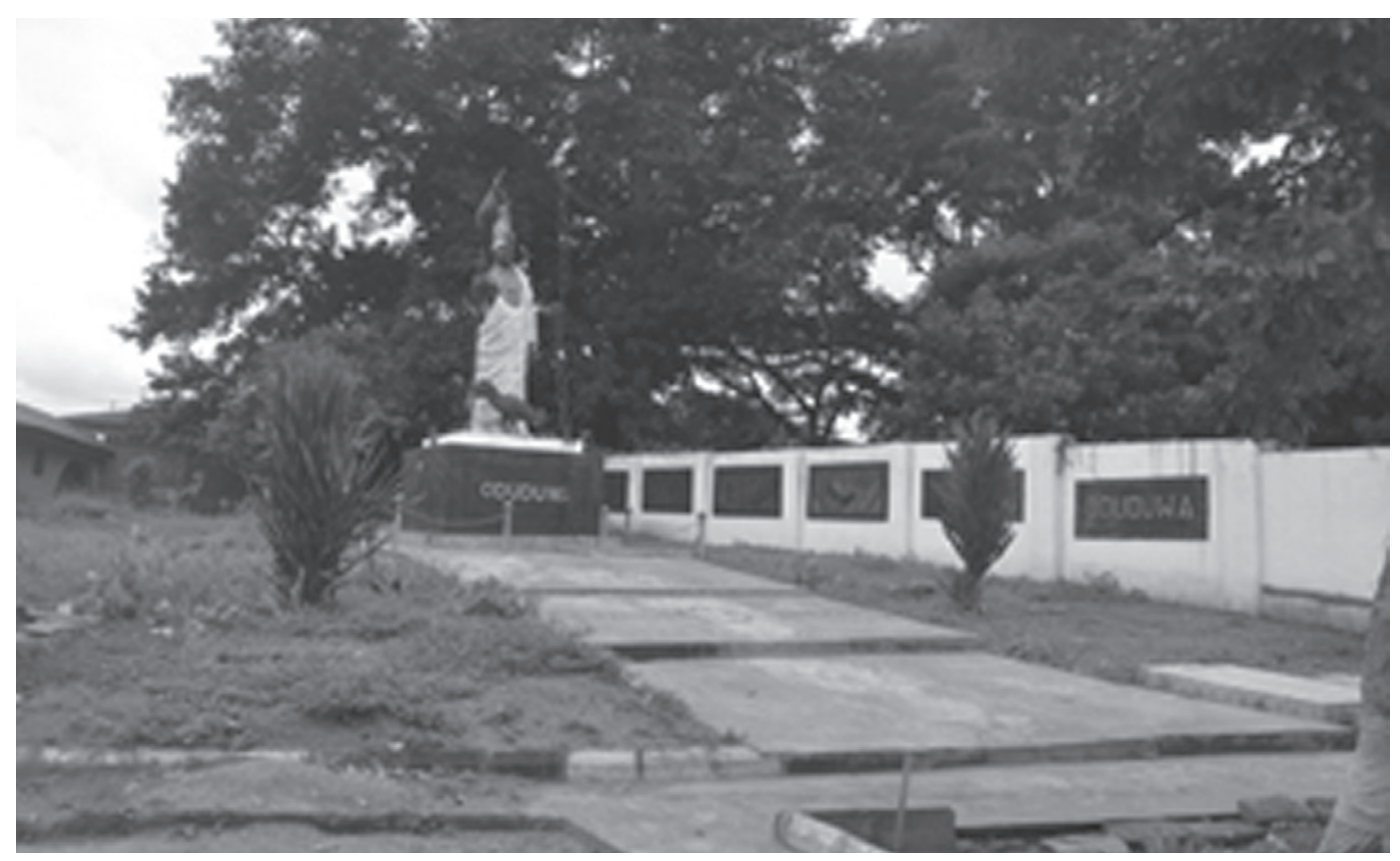

Fig 11: Odùduwà shrine

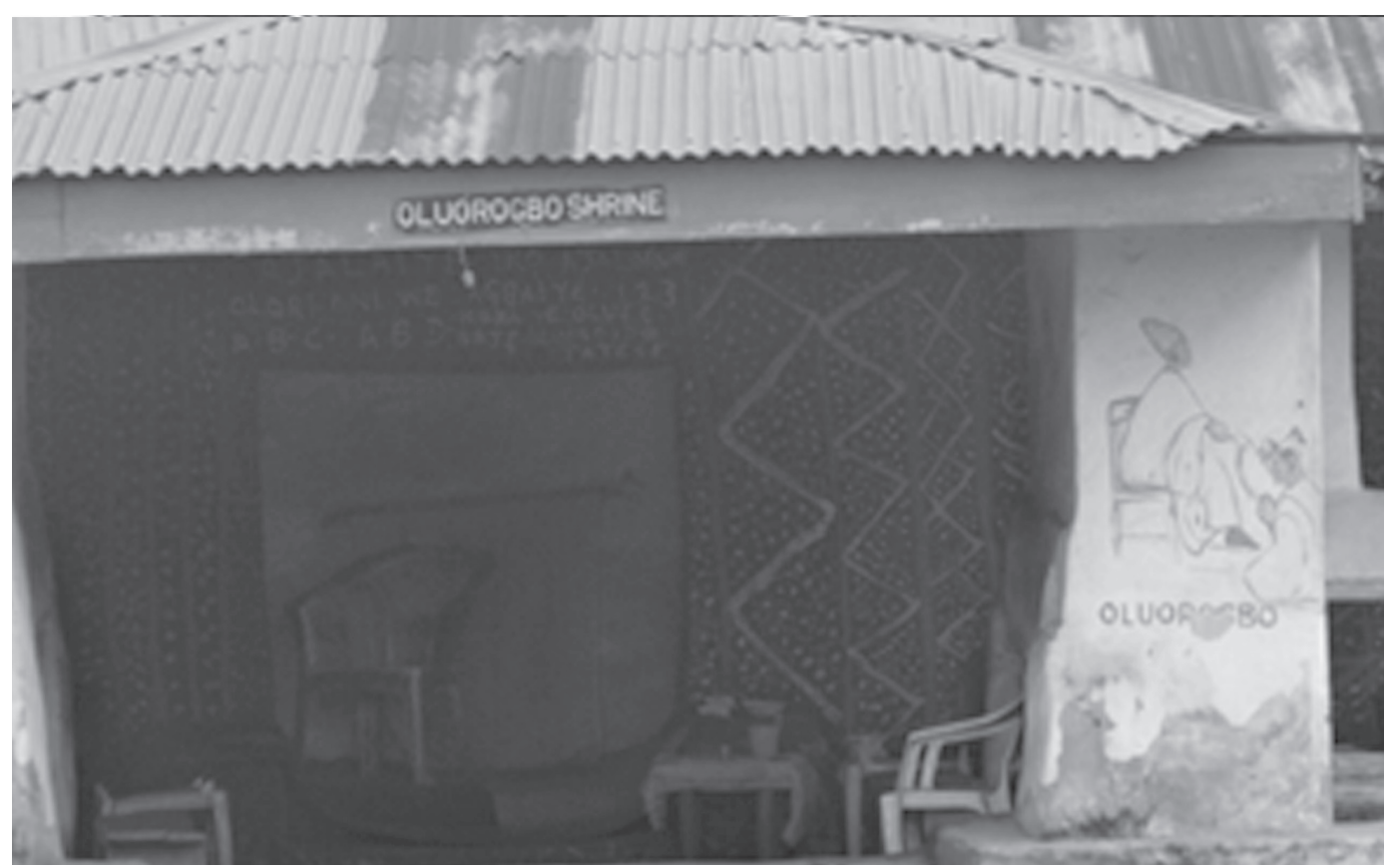

Fig 12: Olúorogbo shrine

From the socio-cultural perspective, we consider the parade of divinities and other cultural elements of the community as providing free knowledge to the guests in physical term. This is a signifier that the heritage is open for further inquiries by guests, and the would-be foreign collaborators to promote 
the festival and for documenting such festive event for economy relevance. The display of the less researched into or known festivals and divinities is also an enabler to researchers who may want to further reach out to the custodian of such festivals. Also, the various songs and chants of each of the divinities paraded at the carnival provide a reminiscences and further insight into the arts of each of the divinities so showcased.

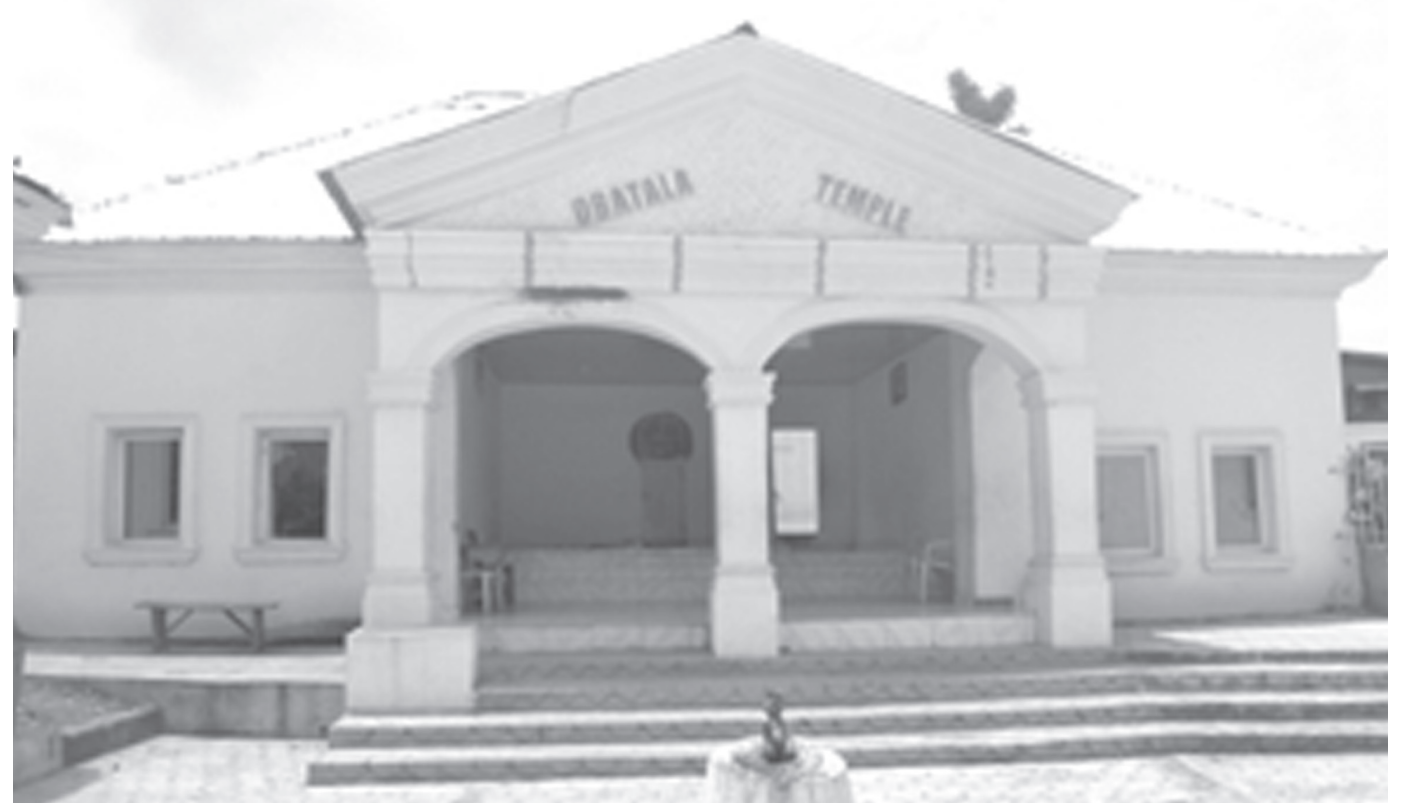

Fig 13: Obàtálá shrine at İtàpá

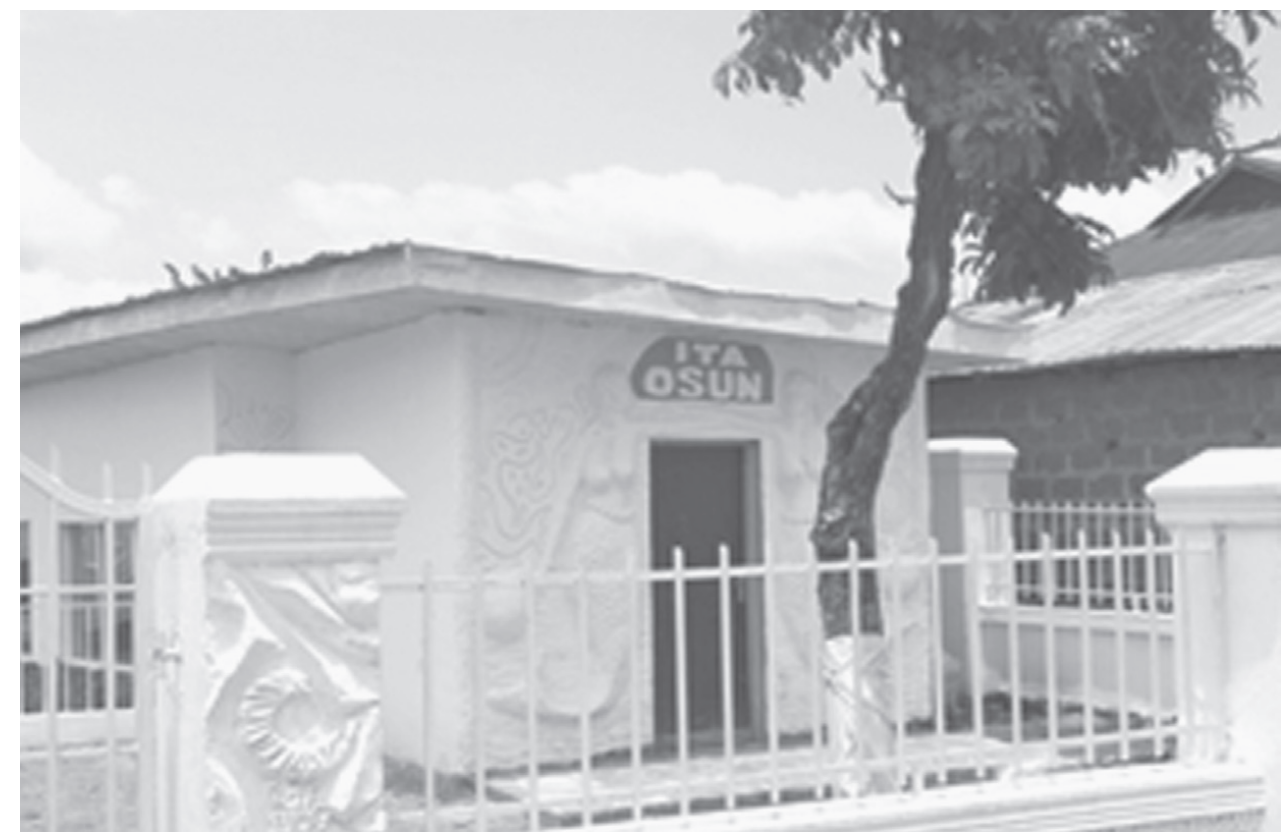

Fig 14: Ọṣun shrine at İta-Ộsun 


\section{Opportunity to Showcase other Ifè Aesthetics to the Outsiders}

As universal as culture is, the culture of Ifẹ̀ with reference to the manners of dance, mode of dress-codes of the chiefs, the tools of performance, their music and language, among other things, stand to be very exceptional in nature. In fact, the structure and content of the festival as shown is evident that Ifẹ festival and other celebrations remain very informative, educative, and entertaining. As evident, the festivities edify the mythology, history, and form the pool of documentation of the people in their yearly royal activities.

Additionally, we consider the parade of divinities and other cultural elements of the community as providing free knowledge to the guests in physical term. This is a signifier that the heritage is open for further inquiries by guests and would-be foreign collaborators to promote the heritage and the performers by providing financial supports, to showcase their culture and for media documentation which could boost the economy of the nation.

\section{Conclusion}

In this study, a selection of three important ancient cultural Ifẹ̀ festivals have been reviewed and intently interrogated through cultural semiotics and sociology of literature apparatus to explicate our findings. These are Olọojọ́, Mọrèmí / Edì, and Ajé festivals. Our analysis supports the views of earlier researchers that the three festivals are still celebrated elaborately in Ilé-Ifẹ̀. It is evident also that while the custodians of the festivals continue to protect and sustain its structural improvement, to channel the festivals towards becoming an international-focus tourist celebration, there is the need to further enhance the festivals as exemplified by the incumbent monarch of Ifẹ̀.

The study concludes that in spite the successes recorded for Ọlọjộ, Mọrèmí/ Edì and Ajé festivals of Ifẹ̀, other Yorùbá communities should also enhance the status of their annual festivals to measure up to the international standard and to serve as source of income generation to their community rather than yearly fun-fair events. The government and other stakeholders are charged to team up to fund the festivals. If most communities are supported by the government, stakeholders, and philanthropists, the cultural wealth of the nation will improve for the best. In our view, most of the festivals have really not enjoyed the deserved significant attention beyond paper reviews and media reports. The array of ancient and cultural festivals in Yorùbáland are enough to create a bulk of economic survival for people if properly monitored, assisted and enhanced.

\section{References}

Adéoyè, C. L. 1979). İgbàgbọ́ àti Ẹsìn Yorùbá. İbàdàn: Evans Publishers. 
Adélegàn, A. (2009). Ilé-Ifè: The Source of Yorùbá Civilization. Ketu, Lagos: Oduduwa International Communications.

Akinbileje, A. and A. Bakare. (2010). "Tradition and Art Appreciation: A Boost to Cultural Tourism in Nigeria" African Research Review, An International Multi-Disciplinary Journal, Vol. 4 (4), Serial No. 17: 506-520.

Danesi, M. (2004). Messages, Signs and Meanings: A Basic Textbook in Semiotics and Communication. Toronto: Canadian Scholars' Press Inc.

Eades, J.S. (1980).The Yorùbá Today. Cambridge: Cambridge University Press. Encyclopedia Americana International Edition, Volume 9, Danbury, 1829.

Escarpit, R. (1971). Sociology of Literature. London: Frank Class and Company Limited.

Fálẹ́yẹ, A. Adéọlá. (2005). "Ẹkà Kíkà Performative Aspect of Ilé-Orò Festival in İlá-Ọràngún of the South-Western Nigeria." Unpublished: M.A. Dissertation of Department of Linguistics and African Languages, Faculty of Arts. University of İbàdàn, İbàdàn, Nigeria.

Fálẹ́yẹ, A. Adéọlá. (2015) “A Semiotic Investigation of Àwòrò-Ọsẹ́ and İsìnrò Festivals among the İlá-Ọràngún İgbómìnà People of Southwestern Nigeria" Unpublished doctoral dissertation, Department of Linguistics and African Languages, Faculty of Arts. University of İbàdàn. İbàdàn.

Finnegan, R. (2007). The Oral and Beyond: Doing things with Words in Africa. Chicago: University of Chicago Press.

Ilésanmí, T.M. (2004). Yorùbá Orature and Literature: A Cultural Analysis. Ifẹ̀: Obafemi Awolowo University Press

Ògúnfọlákàn, B.A. (1996). "Archeological Survey of the North-east of Òsun State, Nigeria." In 'WAAA/AOAA Conference Proceedings', November, pp. $157-171$.

Olúpònà, J.K. (1991). Kingship, Religion and Ritual in a Nigerian Community: APhenomenological Study of Ondo Yorùbá Festivals. Stockhlom, Sweeden: Almqvist and Wiksell International.

Olupona, J.K. (2011). City of 201 Gods: Ilé-Ifè in Time, Space, and the Imagination. Berkeley: University of California Press.

Ògúndèjì, P.A. (1988). “A Semiotic Study of Duro Ladiipo's Mythico-Historical Plays" Unpublished doctoral dissertation, University of Ibadan.

Ògúndèjì, P.A. (1999). "Ritual as Drama and Drama as Ritual." A paper presented at a session 371 of the Salzburg, Austria.

Ògúndèjì, P.A. (2000). "Ritual as Theatre, Theatre as Ritual." İsẹse Monograph series. Vol. 2, no 1. İbàdàn Cultural Studies Group. University of Ibadan.

Pemberton, J. III and Afolayan. S. (1996), A Sacred Power like that of the Gods: Festivals of İlá-Òràngún. Califonia Los: Angeles.

Pemberton, J. III (1996), „Festivals and Sacred Kingship among the Yorùbá İgbómìnà National Geographical Research, Vol. II. 1986. Pp. 87.

Thorpe, C.O. (1967). Àwọn Ėèwọ Ilẹ Yorùbá. Ibadan: Onibon-oje Press. 